\title{
Increasing the Displacement Ductility Factor of Spun Pile Using Concrete Infill
}

\author{
Candra Irawan $^{\mathrm{a}, 1}$, Faimun ${ }^{\mathrm{a}, 2}$, Rudy Djamaluddin ${ }^{\mathrm{b}}$, I Gusti Putu Raka ${ }^{\mathrm{a}, 3}$, Priyo Suprobo ${ }^{\mathrm{a}, 4}$, \\ Gambiro Soeprapto ${ }^{c}$ \\ ${ }^{a}$ Department of Civil Engineering, Institut Teknologi Sepuluh Nopember, Surabaya 60111, Indonesia \\ E-mail:. ${ }^{1}$ chandra@ce.its.ac.id, ${ }^{2}$ faimunf@gmail.com, ${ }^{3}$ raka@ce.its.ac.id, ${ }^{4}$ priyo@ce.its.ac.id \\ ${ }^{b}$ Department of Civil Engineering, Universitas Hasanuddin, Gowa 92171, Indonesia \\ E-mail: rudy0011@gmail.com \\ ${ }^{c}$ PT Wijaya Karya Beton, Tbk., Jakarta 13340, Indonesia \\ E-mail: gambiro.s@wika-beton.co.id
}

\begin{abstract}
Displacement ductility is one of the parameters used to measure the seismic performance of a structure. This study experimentally determines the increase in displacement ductility of the spun pile with $400 \mathrm{~mm}$ of outer diameter and $100 \mathrm{~mm}$ of wall thickness using concrete infill cast inside the hollow of the pile. The spun pile and concrete infill's concrete compressive strength was 54.4 MPa and 33.0 MPa, respectively. Loading was conducted with constant axial and reversed lateral flexural loads. A total of six samples were tested with different axial loads of $392 \mathrm{kN}\left(0.08 \mathrm{fc}^{\prime} \mathrm{Ag}\right)$ for S-DB-1, S-DB-2, S-DB-5, and $784 \mathrm{kN}(0.16 \mathrm{fc}$ 'Ag) for S-DB-3, S-DB-4, S-DB-6 with the reverse flexure load applied in the middle span of the pile. The results showed spun piles with concrete infill could resist the flexural load combined with axial loads until the displacement ductility 5.8 for $P_{0}=0.08 f c^{\prime} A g$, and 3.7 for $P_{0}=$ 0.16f''Ag, respectively. Compared with the ordinary spun piles, which had a hollow section, the presence of concrete infill due to the presence of the concrete infill the displacement ductility increased by $18 \%$ when loaded with $0.08 f^{\prime} \mathrm{cAg}$ and $42 \%$ at $0.16 \mathrm{f}^{\prime} \mathrm{cAg}$ of axial loads. In conclusion, according to seismic codes, displacement ductility evaluation showed that tested piles for plastic concept design applications are appropriate for moderate seismic risks category state under axial loads of $0.08 f c^{\prime} \mathrm{Ag}$. The increasing of the axial load becomes $0.16 \mathrm{fc}^{\prime} \mathrm{Ag}$ decreasing the displacement ductility to become less than 4 , applicable for low seismic risks category state.
\end{abstract}

Keywords — spun pile; displacement ductility; concrete infill.

\section{INTRODUCTION}

The analysis showed that severe damages occurred on the upper and substructure or foundation buildings in Japan after an earthquake. Similarly, spun pile foundation and damaged piles were depicted from excavation during post-earthquake. For instance, after the Miyagiken-Oki (1978) and Hyogokennanbu (Kobe) (1995) earthquakes, some spun pile foundation suffered severe damage, as shown in Fig. 1. The failures were caused by the flexure, shear, compression, or a combination of these forces [1], [2].

Besides, piles were embedded in the ground and also used as freestanding columns constructing marine-related structures such as bridges. Budek and Priestly [3] illustrated the moment pattern on the pile shaft due to lateral load as shown in Fig. 2. According to the head condition, there are two types of pile structures, i.e., free head and fixed head condition. The maximum moment potentially occurs on the pile shaft section which is embedded in the soil for both head conditions. At the same time, the additional maximum moment occurs on the pile section under the pile head in a fixed condition. The pile section that is emerging above the soil was freely deflected without soil resistance [3].

This research primarily determines the increase in displacement ductility of the spun pile using concrete infill with constant axial and reversed lateral flexural loads. The concrete infill was applied to prevent the inwards crushing of the compression concrete that caused the hollow prestressed pile to undergo a brittle failure, as predicted by previous studies [4]. The wall explosion inside the face occurred on a hollow pile [5] with greater confinement of the concrete core needed to provide greater ductility in terms of bending capacity $[6,7]$. Concrete infilling as the core of the pile section contribute to increasing the flexural strength with the ductility factor discussed in this study [8]. This research also determined the axial load effects on the pile 
flexural performance with a further analysis of suitable seismic risk designation according to the seismic codes. This study is focused on a spun pile that applicated as a freestanding column above the soil. Therefore, the confinement effect due to soil is ignored. Flexural and axial loading was subjected to the specimens without including the influence of the shear force.
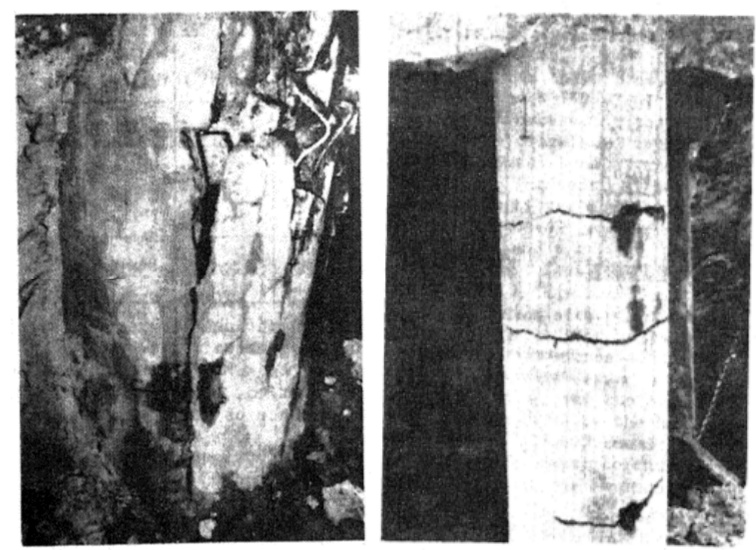

(a). Miyagiken-Oki earthquake 1978

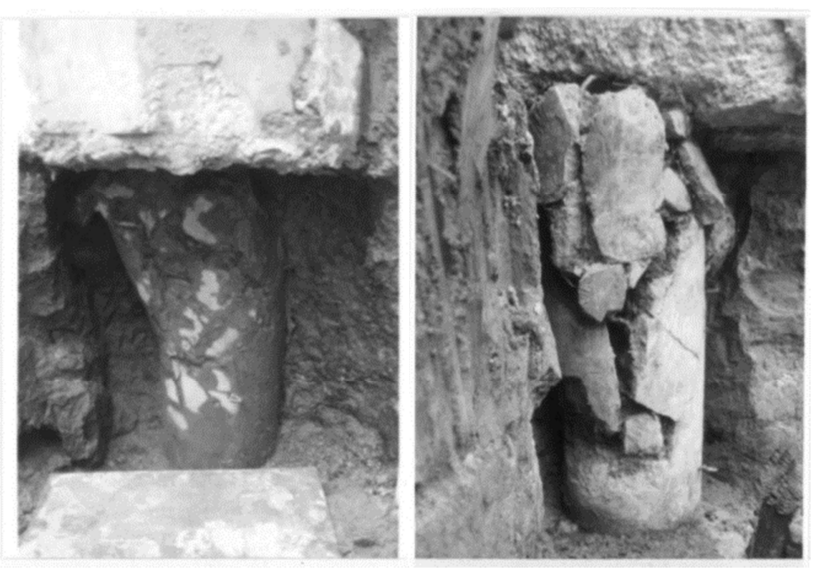

(b) Hyogoken-nanbu (Kobe) earthquake 1995

Fig. 1 Spun pile damage after the earthquake [1],[2]

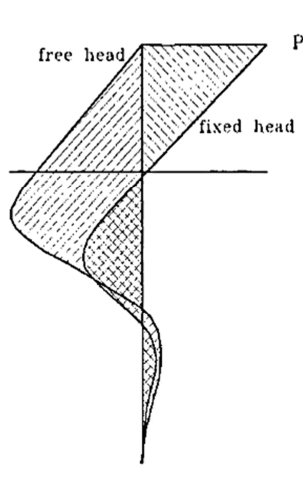

Moment Patterns

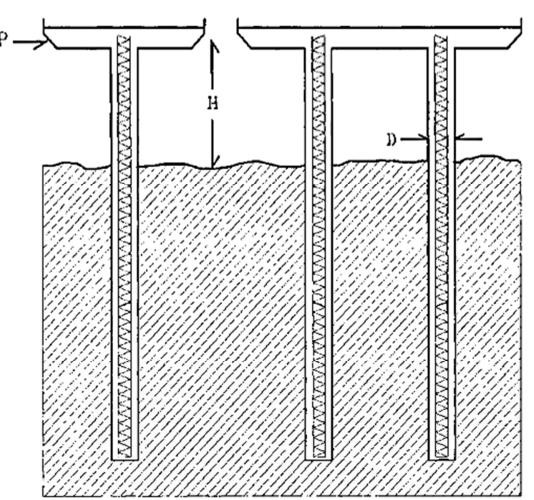

Free Head

Fixed Head
Fig. 2 Moment patterns in free and fixed-head piles [3]

Ikeda et al. [9] carried out research to determine damages to the spun pile after earthquakes. The specimens were hollow piles with outer diameters of $400 \mathrm{~mm}$ and a wall thickness of $70 \mathrm{~mm}$. The average compressive strength of concrete of the pile was 87.4 MPa. This study aimed to observe the effect of transverse reinforcement ratio and the presence of non-prestressed longitudinal steel. Piles tested by one point lateral load at midspan (unidirectional and cyclic loading) as simply supported with a span of $2.6 \mathrm{~m}$ without axial load. The conclusions were adequate core confinement provided by close spacing of transverse reinforcement produces a ductile hollow pile. Piles using non-prestressed longitudinal reinforcement, i.e., deformed bars and unstressed tendons, also had a ductile behavior reaching $\mu 13$ due to unidirectional lateral loading and ductility factor $\mu 8$ under cyclic lateral loading [9].

In Muguruma's study [10], spun piles with high strength concrete, i.e., 95-106 $\mathrm{MPa}$ were tested using one point unidirectional lateral midspan without axial load. The pile section prestress was $10 \mathrm{MPa}$. The pile test configuration was simply supported with a span of $5 \mathrm{~m}$. Piles had an outer diameter of $400 \mathrm{~mm}$, and a wall thickness of $150 \mathrm{~mm}$, twice thicker than Ikeda et al. [9]. The transverse reinforcement using high strength wire in diameters of 5,6 , and $7 \mathrm{~mm}$ with a volumetric ratio from none to $\rho_{t} 0.03$. The yield strength of wire was 1,000 MPa. Furthermore, the study evaluated the maximum uniform elongation of the prestressing bars at $2 \%$ $5.13 \%$. The result showed that the spun pile flexural ductility was proportional to the elongation of the longitudinal steel. High confinement of concrete core provided by sufficient volumetric ratio of transverse reinforcement as confining steel caused crushing damage did not occur on the concrete core section, but the tensile capacity of the longitudinal bars was exceeded on large curvature. Due to longitudinal bar fractures, the mode of failure, such as occurred in this study, is not desirable. The elongation of the prestressing bar should be regarded as its ultimate tensile strain capacity of the pile section [10].

Zahn et al. [11] researched to examine the flexural strength and ductility due to cyclic lateral load and constant axial load by testing six specimens of circular hollow reinforced concrete columns without confining the inner face. All columns had $400 \mathrm{~mm}$ outside diameter varied by wall thickness (t). Specimens 1 and 2 had thickness (t) of $94 \mathrm{~mm}$ tested under an axial load of $0.08 \mathrm{fc}^{\prime} \mathrm{Ag}$ and $0.40 \mathrm{fc}^{\prime} \mathrm{Ag}$, respectively. Specimens 3 and 4 had thickness (t) of $75 \mathrm{~mm}$ tested under an axial load of $0.10 \mathrm{fc}^{\prime} \mathrm{Ag}$ and $0.22 \mathrm{fc}^{\prime} \mathrm{Ag}$. Meanwhile, specimens 5 and 6 had thickness (t) of $55 \mathrm{~mm}$ tested under an axial load of $0.12 \mathrm{fc}^{\prime} \mathrm{Ag}$. In addition, the compressive strength of concrete at 28 days was $29.6 \mathrm{MPa}$ for specimens 1 through 4 and $27.3 \mathrm{MPa}$ for 5 and 6 . The transverse reinforcement of specimens 1,3 , and 4 was $1.13 \%$, while 2,4 , and 6 was $1.36 \%$. The results showed that the expected higher ductility of hollow columns is obtained on the column under low levels of axial load, moderate longitudinal reinforcement ratio, and a wall thickness of the pile section not less than 0.15 of the section diameter. However, the level of confining steel ratio did not significantly affect the ductility capacity of hollow columns [11].

Hoshikuma carried out a research and Priestly [5] associated with the flexural performance of circular columns with a hollow section with $1524 \mathrm{~mm}$ and 1244 outer and 1244 inner diameters, thereby leading to a $140 \mathrm{~mm}$ wall thickness $(t / D=0.092)$. A single layer of longitudinal and 
transverse reinforcement is applied to the column. One of reinforcement was longitudinal with sufficient transverse reinforcement $\rho_{\mathrm{s}}$, which equals $0.22 \%$. The testing carried out under a $0.13 \mathrm{fc}^{\prime} \mathrm{Ag}$ axial load combined with a cyclic lateral load. The test results showed that the columns suddenly failed when concrete on the wall inside face was crushed. It was also found that the plastic hinge region confinement-induced transverse strain did not reach the yield strain before failure. These facts suggest that the limited lateral pressure is induced in the concrete shell. Therefore, the inside face concrete is subjected to poor confinement despite placing the sufficient transverse reinforcement is near the outside face of the hollow columns. Furthermore, the limited column displacement ductility capacity was obtained ( $\mu_{\Delta} 2$ until 4) with the full lateral pressure induced in the core concrete under the triaxial compression and during cyclic lateral loading in the inelastic range. A significant reduction of confinement and the premature crushing of inside face concrete occurred due to biaxial compression of the circular hollow section [5].

In Tuladhar, Mutsuyoshi, Maki, and Daigo's [12] research, One dimensional monotonic and cyclic lateral loading carried out in a single full-scaled spun pile with an outer diameter $300 \mathrm{~mm}$ and a wall thickness $60 \mathrm{~mm}$ without axial load. Piles embedded in the soil up to $24.8 \mathrm{~m}$ from the ground level (GL). The concrete of piles had compressive strength fc' $69 \mathrm{MPa}$. The effective prestress on the concrete was $5 \mathrm{MPa}$. Pile's reinforcement used six PC bars of $7 \mathrm{~mm}$ diameter for a longitudinal bar and a steel wire with $3 \mathrm{~mm}$ of diameter and $100 \mathrm{~mm}$ of spacing as transverse steel. This study aimed to determine the plastic hinge locations, which were formed at a depth twice the diameter of the pile (2D) from the ground level during monotonic loading. Meanwhile, due to lateral cyclic loading, the plastic hinge occurred on the pile shaft on the depth 4D under the GL [12].

In Budek and Priestly [3], this study tested four hollow prestressed piles designated with PS11, PS12, PS13, and PS14 had an outer diameter $610 \mathrm{~mm}$ with a shell thickness of $94 \mathrm{~mm}$. Samples PS11, PS12, PS13 has an average concrete compressive strength that reached $67.5 \mathrm{MPa}$. At the same time, PS14 had fc' 53.5 MPa. The effective section prestress was 7.72 MPa. The cyclic lateral load subjected to the midspan of pile combined with constant axial loads 890 $\mathrm{kN}$ equals $0,87 \mathrm{fc}$ ' $\mathrm{Ag}$. The hinge's external confinement was applied to PS11 and PS14 using saddles made from a rubber that covered $100^{\circ}$ of pile shaft circumference on the top and bottom surface. The testing result showed that piles failed due to the shell's inability to resist the compression stress when the longitudinal strain at the core's inner surface exceeded more than 0.005 . The soil confinement, represented by rubber saddle, and the level of confinement steel ratio on the plastic hinge region do not significantly affect the increase of the displacement ductility capacity of the hollow pile. The bond-slip damage occurred between the surface of non-prestressed longitudinal steel bars and concrete shell. This damage mechanism initiated compression failure and decreased displacement ductility of the hollow pile from $\mu_{\Delta} 4$ to $\mu_{\Delta} 2.5$. Tested piles were recommended to be designed to remain in the elastic condition [3].

\section{A. Codes consideration}

The pile foundation seismic design concept is designated to ensure it has adequate strength to resist the seismic force during an intense earthquake. The first stage of designing a pile foundation under seismic load was determining the total deformation system, pile, and soil interaction, during its occurrence using the pushover analysis method. Furthermore, the designing pile had sufficient seismic performance, strength, and ductility, as stated in the previous structural analysis [13].

The seismic performance (SP) of building foundations in Japan consists of three levels: SPI, SPII, and SPIII. According to NEHRP 2000, the pile's seismic performance consists of three levels, with categories $\mathrm{A}, \mathrm{B}$, and $\mathrm{C}$ corresponding to SPI, while D, E, and F are in SPIII [13, 14]. In the pile foundation seismic design concept, the performance was confirmed by the stability level, which is determined by considering the strength and the deformation of soil and pile members. Tables 1 and 2 show the summary of the ductility factor's limit values for pile according to Japan's code and NEHRP 2000. Both codes illustrated that the minimum ductility factor $\mu \Delta$ provided by a pile foundation for high and moderate seismic risk was 8 and $4 /$ 5 .

TABLE I

State of Pile Foundation AND DUCTILITY FACTOR ACCORDING to SEISMIC PERFORMANCE LEVELS [13]

\begin{tabular}{|l|l|l|c|}
\hline $\begin{array}{c}\text { Seismic } \\
\text { performance }\end{array}$ & $\begin{array}{c}\text { Stability } \\
\text { level }\end{array}$ & State of foundation & $\begin{array}{c}\text { Limit } \\
\text { values of } \\
\text { ductility } \\
\text { factor }\end{array}$ \\
\hline SPI & Level I & $\begin{array}{l}\text { Pile foundation does } \\
\text { not yield. }\end{array}$ & 1 \\
\hline SPII & Level II & $\begin{array}{l}\text { Although pile } \\
\text { foundation yield, they } \\
\text { maintain a sufficient } \\
\text { bearing capacity. }\end{array}$ & 5 \\
\hline SPIII & Level III & $\begin{array}{l}\text { Although the pile } \\
\text { foundation reaches } \\
\text { the limit state, } \\
\text { superstructures do } \\
\text { not collapse. }\end{array}$ & 8 \\
\hline
\end{tabular}

TABLE II

LIMIT VALUES OF DUCTILITY FACTOR ACCORDING TO NEHRP 2000 [14]

\begin{tabular}{|l|l|c|}
\hline $\begin{array}{c}\text { Seismic risk } \\
\text { category }\end{array}$ & $\begin{array}{c}\text { Seismic design } \\
\text { category }\end{array}$ & $\begin{array}{c}\text { Limit values of } \\
\text { ductility factor }\end{array}$ \\
\hline Low & A and B & No requirement \\
\hline Moderate & C & 4 \\
\hline High & D, E, and F & 8 \\
\hline
\end{tabular}

\section{MATERIALS AND METHOD}

\section{A. Specimen Dimensions}

Six spun piles with concrete infill cast inside the spun pile were tested with different axial loads, namely $392 \mathrm{kN}$ (0.08fc'Ag) for S-DB-1 S-DB-2, S-DB-5 and $784 \mathrm{kN}$ (0.16fc'Ag) for S-DB-3, S-DB-4, S-DB-6. The dimensions of the specimens are shown in Fig. 3. The spun pile's outer 
and inner diameters at $400 \mathrm{~mm}$ and $200 \mathrm{~mm}$ produce a thickness $(\mathrm{t} / \mathrm{D}=0.25)$ value of $100 \mathrm{~mm}$ of the thickness, as shown in Fig. 3. One layer reinforcement consisted of ten bars of PC bar $\varnothing 7.1 \mathrm{~mm}$ were embedded to pile and placed near the outside face of the section with a concrete cover of $35 \mathrm{~mm}$. The transverse steel bars used steel wire with diameter $\varnothing 3.2 \mathrm{~mm}$ and $100 \mathrm{~mm}$ of spacing. The pile's crosssection and reinforcement's detail are shown in Fig. 3.

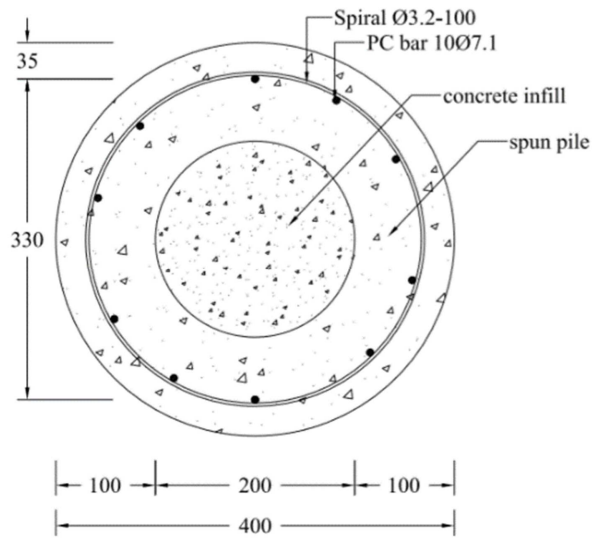

Fig. 3 Cross-section and reinforcement detail of specimens

\section{B. Properties of materials}

The specimens consist of the spun pile and infill concretes. The compressive strength at 28-days age of concrete of spun pile and concrete infill was $54.4 \mathrm{MPa}$ and $33.0 \mathrm{Mpa}$, respectively. Fig. 4 shows the PC's tensile properties with a bar and spatial wire diameters of $7.1 \mathrm{~mm}$ and $3.2 \mathrm{~mm}$. The PC bar's cross-sectional area and the wires were $39.6 \mathrm{~mm} 2$ and $8 \mathrm{~mm} 2$, with a modulus of elasticity of 229,577 Mpa, and 219,774 Mpa. The PC bar reached yield, and the ultimate condition at stress level was 1,387 Mpa and 1,455 Mpa, while wire attained ultimate state at a stress level of $712 \mathrm{Mpa}$. The PC bar's yield and ultimate strain were 0.007 and 0.023 , with an ultimate strain of 0.02 .

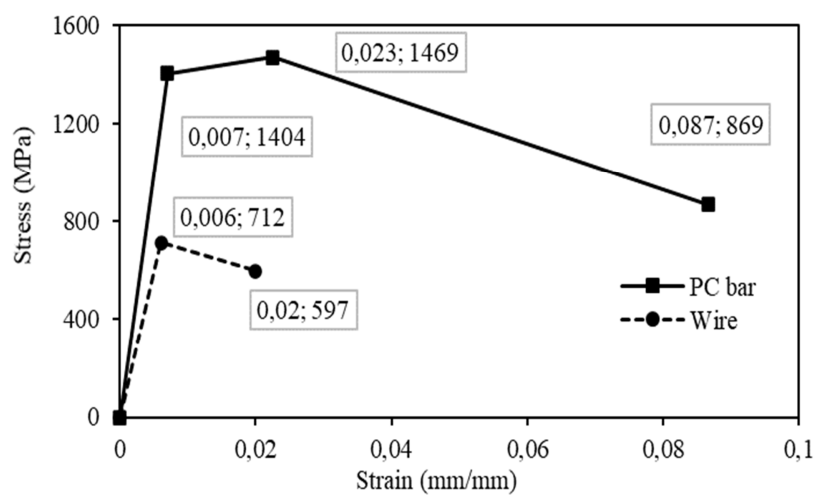

Fig. 4 Tensile stress-strain relationship of PC bar and spiral reinforcement

\section{Loading Setup}

The spun pile, which is vertically simply supported, was tested, as shown in Fig. 5a. The picture of the testing setup in the laboratory was depicted in Fig. 5b. Both ends of the pile were supported using a pin. For transferring the axial force generated by hydraulic compression stressing jack to the pile's shaft, upper hole support was designed as an oval shape. Constant axial loads, $392 \mathrm{kN}$ (0.08 fc' Ag), and 784 $\mathrm{kN}(0.16 \mathrm{fc} \mathrm{Ag})$ represent gravity loads subjected to the top of the spun pile. The reverse lateral load, representing the seismic load, was imposed as two points loading in the spun pile's middle span using a push and pull actuator.

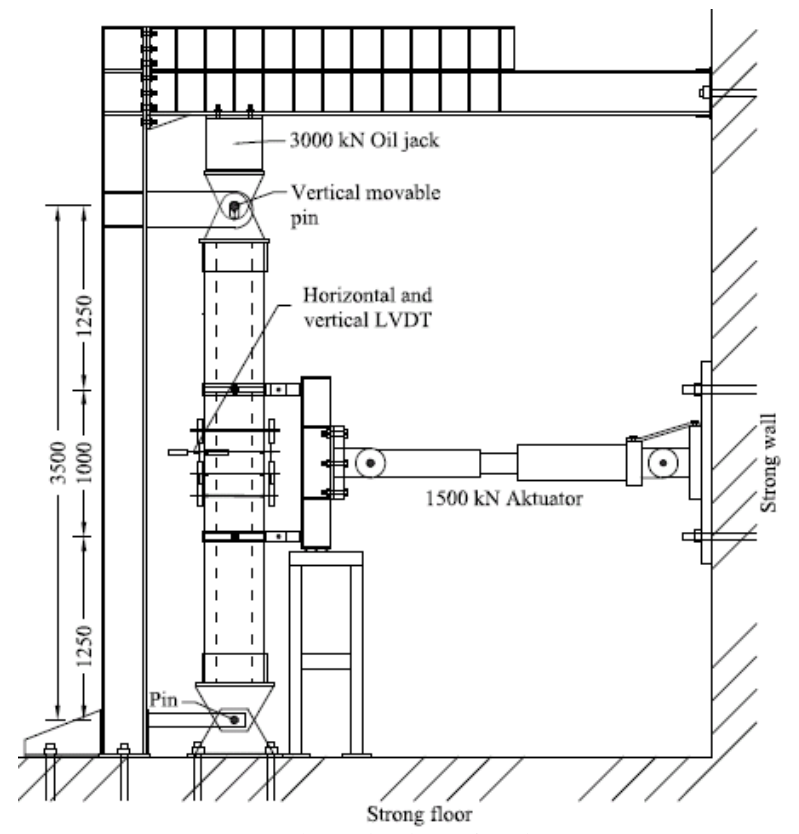

(a) Schematic view of testing setup

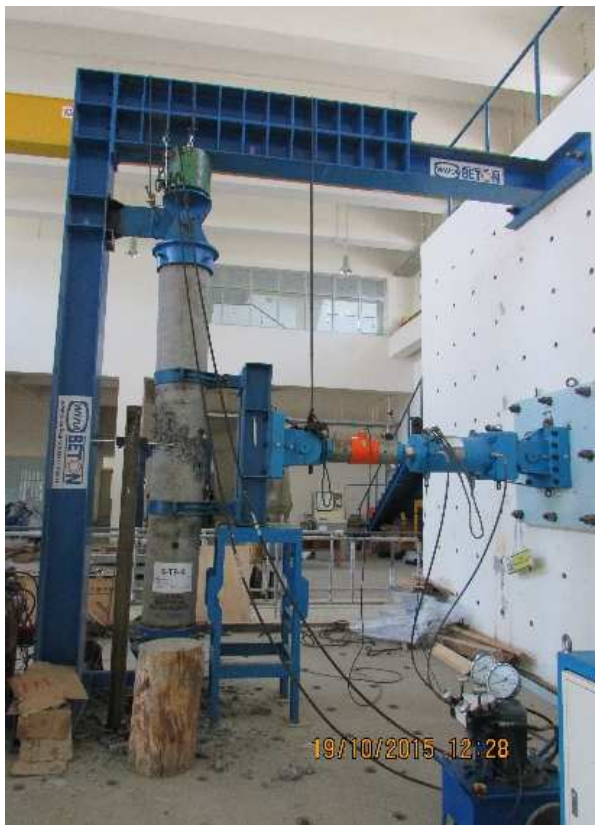

(b) Implementation in laboratory

Fig. 5 Test setup of specimen and loading system for cyclic flexural with axial load testing

The lateral displacement was measured using a $100 \mathrm{~mm}$ Linear Variable Differential Transducer (LVDT) mounted in the midspan. The value of the drift ratio obtained by dividing the recorded lateral displacement and half of the shear span. Furthermore, sequence cycles of the drift ratio for reverse cyclic loading of ACI 374-1-05 were shown in Fig. 6. Constant reverse displacement was repeated in three cycles, with an increase in drift ratio until the pile failed [15]. 




Fig. 6 The Sequence of drift ratio according to ACI 347-1-05 [15]

\section{RESULTS AND DISCUSSION}

A. The Curve of Hysteresis Loops of The LoadDisplacement

The hysteresis curves of the load-displacement relationship of tested spun pile under combined reversed flexural and constant axial load were shown in Fig. 7 and 8. Two cases were analyzed from these curves, with the first regarding the displacement ductility factor. In contrast, the second is related to the seismic performance of spun pile according to Japan's code and NEHRP 2000.

The spun pile's average displacement ductility factor with concrete infill tested under axial loads of $392 \mathrm{kN}\left(0.08 \mathrm{f}^{\prime} \mathrm{cAg}\right)$ and $784 \mathrm{kN}\left(0.16 \mathrm{f}^{\prime} \mathrm{cAg}\right)$ was 5.8 and 3.7 , respectively as shown in Table 3 . The ordinary spun pile i.e. without concrete infill had an average displacement ductility 4.9 and 2.6, under axial loads $0.08 \mathrm{f}^{\prime} \mathrm{cAg}$ and $0.16 \mathrm{f}^{\prime} \mathrm{cAg}$, respectively [16]. Therefore, due to the concrete infill's presence, the displacement ductility increased by $18 \%$ when loaded with $0.08 f^{\prime} \mathrm{cAg}$ and $42 \%$ at $0.16 \mathrm{f}^{\prime} \mathrm{cAg}$ of axial loads.

TABLE III

THE SUMMARY OF DisPLACEMENT DUCTILITY FACTOR OF SPUN PILE WITH CONCRETE INFILL

\begin{tabular}{|c|c|c|c|}
\hline Axial load & Sample & $\begin{array}{c}\text { Displacement } \\
\text { ductility, } \mu_{\Delta}\end{array}$ & $\mu_{\Delta}$ average \\
\hline \multirow{3}{*}{$\begin{array}{l}392 \mathrm{kN} \\
\left(0.08 \mathrm{fc}^{\prime} \mathrm{Ag}\right)\end{array}$} & S-DB-1 & 5.9 & \multirow{3}{*}{5.8} \\
\hline & S-DB-2 & 5.8 & \\
\hline & S-DB-5 & 5.7 & \\
\hline \multirow{3}{*}{$\begin{array}{l}784 \mathrm{kN} \\
\left(0.16 \mathrm{fc}^{\prime} \mathrm{Ag}\right)\end{array}$} & S-DB-3 & 3.1 & \multirow{3}{*}{3.7} \\
\hline & S-DB-4 & 3.9 & \\
\hline & S-DB-6 & 4.1 & \\
\hline
\end{tabular}

TABLE IV

The SumMary of DisPlacement Ductility FaCtor of SPUN PILE WITHOUT CONCRETE INFILL [16]

\begin{tabular}{|l|c|c|c|}
\hline \multicolumn{1}{|c|}{ Axial load } & Sample & $\begin{array}{c}\text { Displacement } \\
\text { ductility, } \boldsymbol{\mu}_{\boldsymbol{\Delta}}\end{array}$ & $\begin{array}{c}\boldsymbol{\mu}_{\boldsymbol{\Delta}} \\
\text { average }\end{array}$ \\
\hline $392 \mathrm{kN}$ & S-TB-1 & 4.8 & \multirow{2}{*}{4.9} \\
\cline { 2 - 3 }$\left(0.08 \mathrm{fc}^{\prime} \mathrm{Ag}\right)$ & S-TB-2 & 4.9 & \\
\hline $784 \mathrm{kN}$ & $\mathrm{S}-\mathrm{TB}-3$ & 2.4 & 2.6 \\
\cline { 2 - 3 }$\left(0.16 \mathrm{fc}^{\prime} \mathrm{Ag}\right)$ & $\mathrm{S}-\mathrm{TB}-4$ & 2.8 & \\
\hline
\end{tabular}

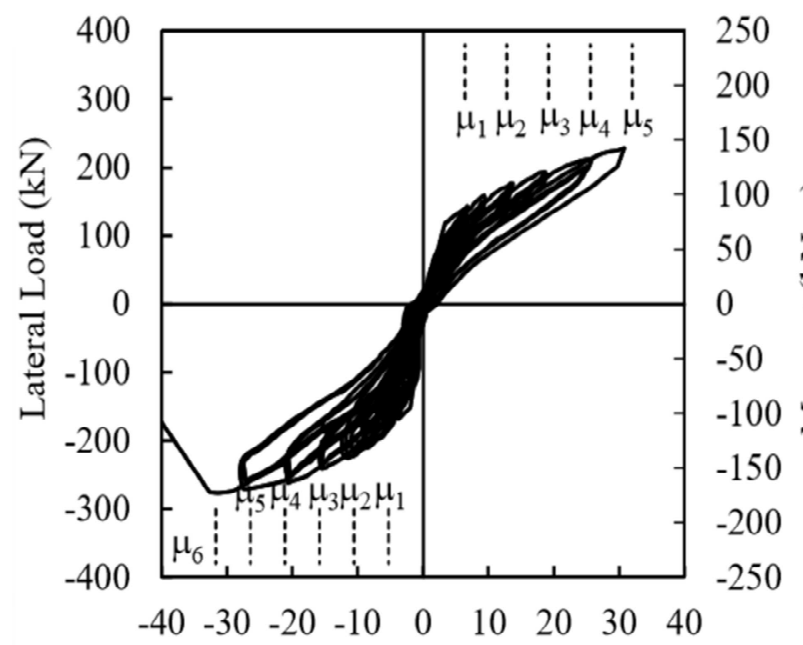

Displacement ( $\mathrm{mm})$

a) S-DB-1

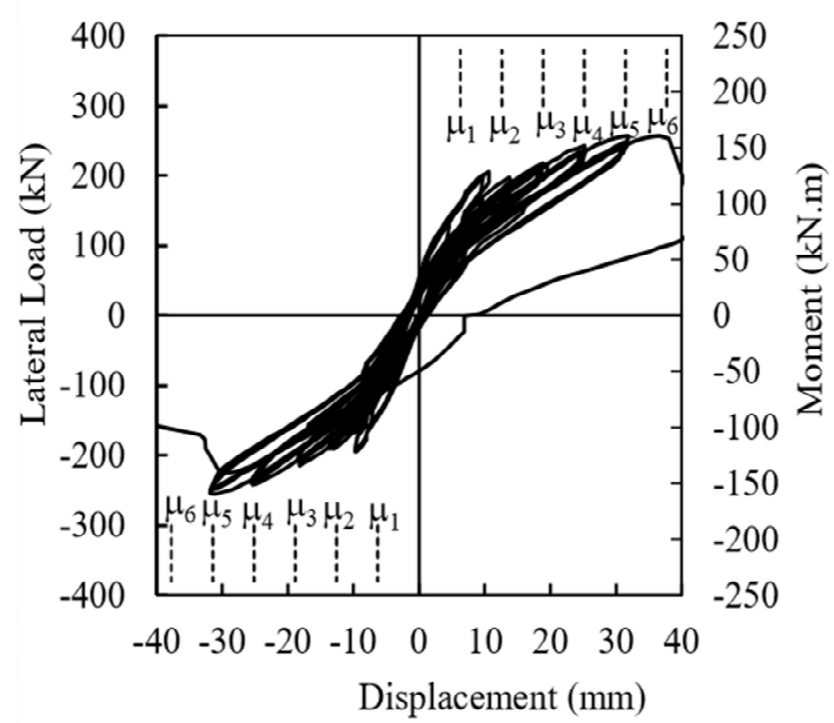

b) S-DB-2

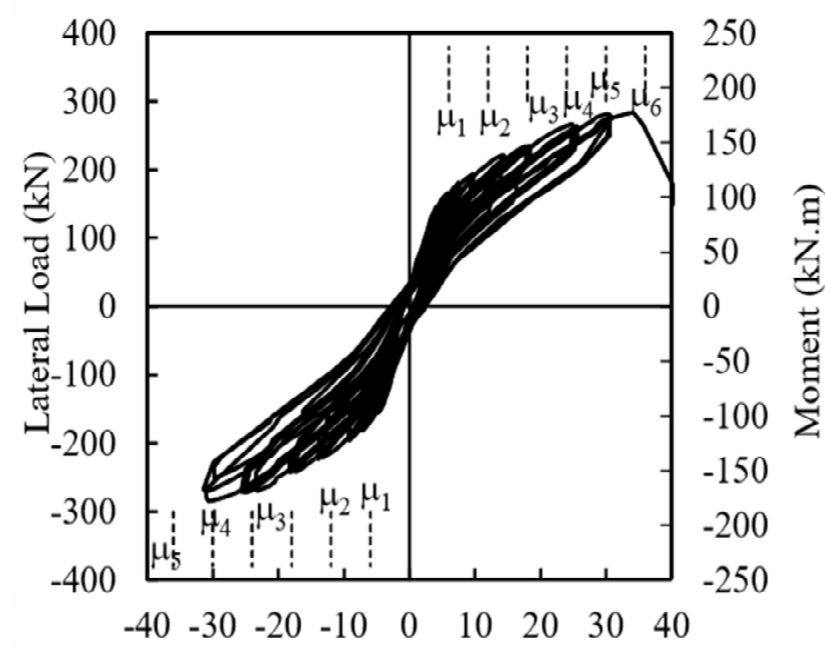

Displacement (mm)

c) S-DB-5

Fig. 7 The hysteresis load-displacement of the spun pile with concrete infill under $392 \mathrm{kN}(0.08 \mathrm{fc}$ 'Ag) of axial load 


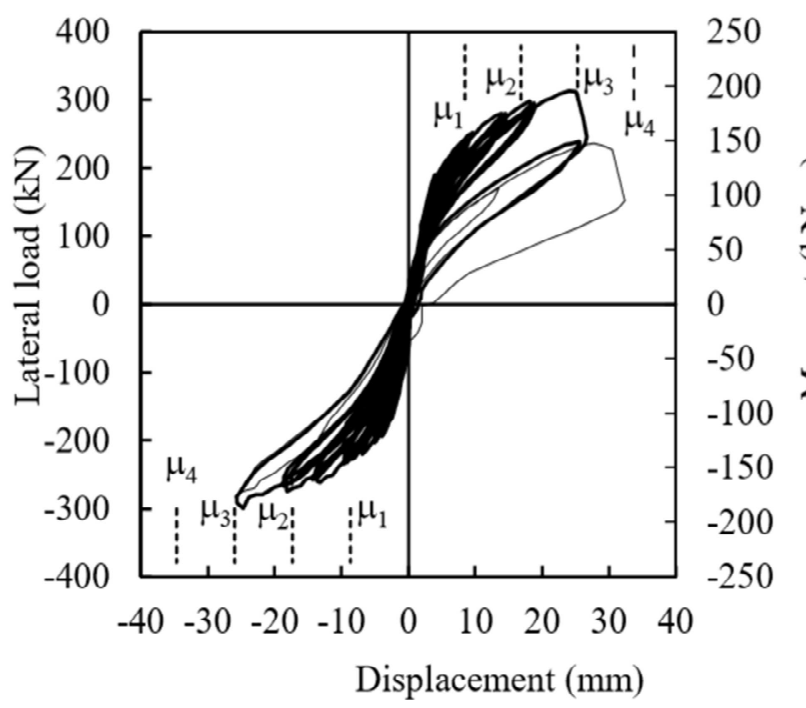

a) S-DB-3

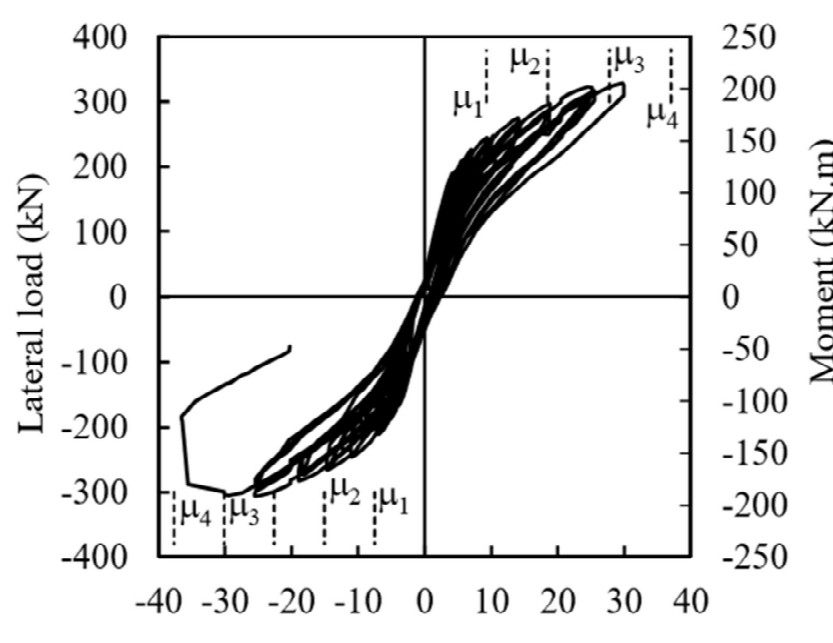

Displacement (mm)

b) S-DB-4

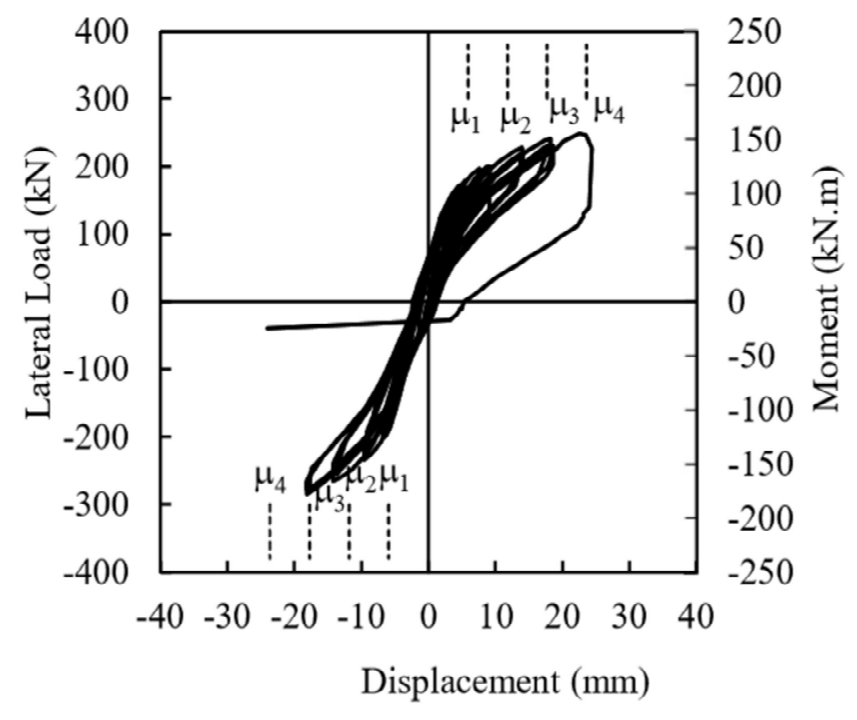

c) S-DB-6

Fig. 8 The hysteresis load-displacement of the spun pile with concrete infill under $784 \mathrm{kN}(0.16 \mathrm{fc}$ 'Ag) of axial load

\section{B. Displacement Analysis of The Ductility Factor According to Seismic Code Requirements}

The ductility factor's displacement analysis as the spun pile's seismic performance parameter was carried out by comparing the ductility factor with the limit factor requirements regulated by seismic design codes. The purpose of this analysis was to classify the appropriate application of tested pile according to the seismic risk category (SRC) or Seismic Design Category (SDC) and its stability level.

According to the previous analysis, the spun pile's average displacement ductility factor with concrete infill was 5.8 for specimens tested under $0.08 \mathrm{fc}^{\prime} \mathrm{Ag}$ axial load and 3.7 for $0.16 \mathrm{fc}^{\prime} \mathrm{Ag}$, as shown in Fig. 9. The piles of foundations were permitted to attain yield state with sufficient bearing capacity by using a stability level of II. Meanwhile, applying $0.16 \mathrm{fc}^{\prime} \mathrm{Ag}$ of an axial load on tested spun pile, obtained a ductility level of less than 5 , due to the stability of the caused pile foundations in level I. These piles were used in low seismic risk category which means that $0.16 \mathrm{fc}^{\prime} \mathrm{Ag}$ axial load-induced spun pile needs to be designed in an elastic state. At $0.08 \mathrm{fc}^{\prime} \mathrm{Ag}$, it was permitted to be designed as partial ductile members.

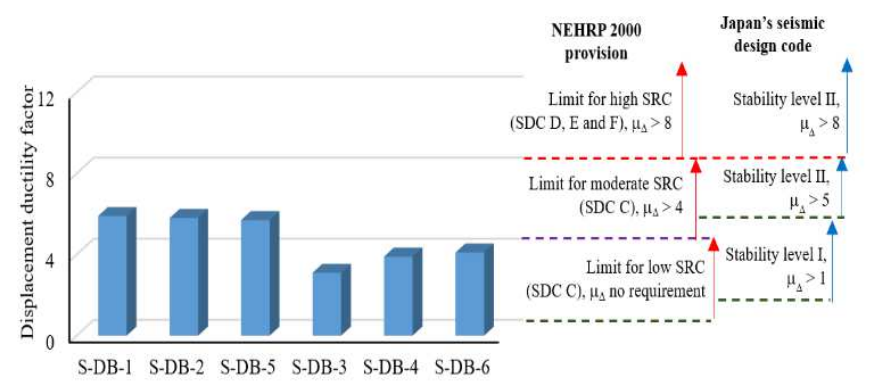

Fig. 9: State of displacement ductility factor of tested specimens according to seismic codes requirement

\section{CONCLUSION}

This experimental research provides several illustrations showing the influence of concrete infill on the spun pile's flexural performance. Seismic performance of spun pile with concrete infill can be used up to medium risk when the axial loads were $392 \mathrm{kN}\left(0.08 \mathrm{f}_{\mathrm{c}}^{\prime} \mathrm{A}_{\mathrm{g}}\right)$ and $784 \mathrm{kN}\left(0.16 \mathrm{f}^{\prime} \mathrm{cAg}\right)$ with displacement ductility of 5.8 and 3.7 , respectively. The presence of concrete infill increases the average spun pile displacement ductility by $18 \%$ when loaded with $392 \mathrm{kN}$ $\left(0.08 f^{\prime} \mathrm{cAg}\right)$ and $42 \%$ at $784 \mathrm{kN}\left(0.16 f^{\prime} \mathrm{cAg}\right)$ axial loads. According to Japan's code and NEHRP 2000 requirement, tested spun piles with concrete infill were appropriately used in moderate and low seismic risk categories under $0.08 \mathrm{fc}^{\prime} \mathrm{Ag}$ and $0.16 \mathrm{fc}^{\prime} \mathrm{Ag}$ axial loads. Further research is needed to investigate the effect of providing adequate spiral reinforcement to confine concrete core. The objective is to obtain a displacement ductility factor more than 8 . Therefore, the spun pile has sufficient ductility to be applied to the high seismic risk category.

\section{NOMENCLATURE}

f stess

$\mathrm{MPa}$
$\mathrm{mm}^{2}$

A area 


\section{Greek letters}

$\mu \quad$ ductility factor

$\rho \quad$ ratio of reinforcement

$\varnothing \quad$ diameter of steel bars

\section{Subscripts}

$\begin{array}{ll}\Delta & \text { displacement } \\ \mathrm{c} & \text { concrete } \\ \mathrm{g} & \text { gross }\end{array}$

\section{ACKNOWLEDGMENT}

The authors are grateful to PT Wijaya Karya Beton, Tbk. for funding this study, by collaborating with ITS Surabaya and UNHAS Makassar under contract number: KU.09.09/WB-0A.1763/2014, 098SK/LB3/XII/2014, 028/UN4.8/TS-LSB/PM05/2014.

\section{REFERENCES}

[1] H. Kishida, T. Hanazato, and S. Nakai, "Damage of reinforced precast piles during the Miyagi-Ken-Oki earthquake of June 12, 1972”, Proceedings of the Seventh World Conference on Earthquake Engineering, Istanbul, Turkey, 1980, vol. 9.

[2] H. Mizuno, M. Iiba, and T. Hirade, "Pile Damage during 1995 Hyougoken-Nanbu Earthquake in Japan", Proceeding of Eleventh World Conference on Earthquake Engineering, 1996, Paper No. 977.

[3] A. M. Budek, and M. J. N. Priestly, "Experimental Analysis of Flexural Hinging in Hollow Marine Prestressed Pile Shaft", Coastal Engineering Journal, vol. 47, no. 1, pp. 1-20, 2005.

[4] S. Banerjee, J. F. Stanton, and N. M. Hawkins, "Seismic Performance of Precast Prestressed Concrete Piles". Journal of Structural Engineering, vol 113(2), pp. 381-396, 1987.

[5] J. Hoshikuma, and M. J. N. Priestley, (2000). "Flexural Behavior of Circular Hollow Columns with a Single Layer of Reinforcement under Seismic Loading". Final Research Report for Caltrans under Contract No. 59A0051.

[6] J. b. Mander, M. J. N. Priestly, R. Park, "Observed Stress-Strain Behavior of Confined Concrete", Journal of Structural Engineering, vol. 114(8), pp. 1827-1849, 1988.

[7] M. C. Nigels, "Design of Prestressed Concrete Piles for Seismic Load Adds a New Dimension”, Piledriver, Q4, pp. 32-36, 2005.

[8] M. Akiyama, S. Abe, N. Aoki, and M. Suzuki, "Flexural Test of Precast High-strength Reinforced Concrete Pile Prestressed with Unbonded Bars Arranged at the Center of the Cross-section", Engineering Structures Journal, vol.34, pp. 259-270, 2012.

[9] S. Ikeda, T. Tsubaki, and T. Yamaguchi, "Ductility improvement of prestressed concrete piles," Transactions of the Japan Concrete Institute, vol. 4, pp. 531-538, 1982.

[10] H. Muguruma, F. Watanabe, and M. Nishiyama, "Improving The flexural Ductility of Pretensioned High Strength Spun Concrete Piles by Lateral Confining of Concrete", Proceedings of the Pacific Conference on Earthquake Engineering, Wairakei, New Zealand, 1987, Vol. 1, pp. 385-396.

[11] F. A. Zahn, R. Park, and M. J. N. Priestly, "Flexural Strength and Ductility of Circular Hollow Reinforced Concrete Columns without Confinement on Inside Face", ACI Structural Journal, no 87-S17, pp. 156-166, March-April 1990.

[12] R. Tuladhar, H. Mutsuyoshi, T. Maki, and K. Daigo, "Lateral Loading Tests of Full Scaled Concrete Piles Embedded into the Ground", Bulletin of Engineering Faculty Saitama University, no. 38, pp. 74-80, 2005

[13] N. Takase, M. Ikegame, S. Tanamura, A. Nishimura, and M. Kondou, "Seismic Design of Pile Foundation", $Q R$ of RTRI, vol. 40 no.3, pp. 152-157, 1999.

[14] N.M. Hawkins, and S.K. Ghosh, "Proposed Revisions to 1997 NEHRP Recommended Provisions for Seismic Regulations for Precast Concrete Structure", PCI Journal, pp. 34-44, 2000.

[15] Acceptance Criteria for Moment Frames Based on Structural Testing and Commentary, ACI Committee 347.1, 2005.

[16] C. Irawan, I. G. P. Raka, R. Djamaluddin, P. Suprobo, and Gambiro, "Ductility and Seismic Performance of Spun Pile under Constant Axial and Reverse Flexural Loading", Proceeding of International Symposium on Concrete Technology, Makassar, Indonesia, 2017. 